\title{
Key Determinants for Marketing and Operational Strategies of Hotel Business
}

\author{
Anuar Alias ${ }^{1}$ and Sok Be Tan ${ }^{2}$ \\ ${ }^{12}$ Centre for Construction, Building and Urban Studies (CeBUS), Faculty of Built Environment \\ University of Malaya, Kuala Lumpur \\ 1anuar_a@um.edu.my
}

\begin{abstract}
The main goal of this research is to identify the key determinants on marketing and operational strategies for hotels in the Klang Valley through a study and review of feedback gathered from stakeholders - hotel guests and hotel operators. This research adopted the mixed method of quantitative and qualitative approaches to achieve the objectives. The findings of this research revealed that the top five (5) determinants which are perceived to be of greatest importance in determining the purchase behaviour of hotel guests, and the key determinants of hotels as measured by average room rate. Among the top five (5) determinants, scale, location and service quality were found to be significant variables. The results of this research were largely consistent with the outcome of research conducted by researchers in other publication. It is envisaged that these research findings would be of great interests especially to the hoteliers in devising their marketing and operational strategies such that sufficient focus is given to the key determinants which are of particular importance to hotel guests in driving their decision to select a hotel room.
\end{abstract}

Keywords: hotel, key determinants, marketing, performance, purchase behaviour

\section{INTRODUCTION}

Hotel properties, as an asset class, are unique from many aspects. They are normally "single-use" properties that require specific management expertise, and the value of hotel properties is directly related to their ability to generate future net income (Crick \& Spencer, 2011; Nilsson et al., 2001; Quintal \& Pollczynski, 2010; Vandell, 2007). Malaysia has witnessed a proliferation of attention and focus on the tourism industry as one of the key sectors of economic growth amidst the $10^{\text {th }}$ Malaysia Plan and the Economic Transformation Program (ETP). In line with this phenomenon, there is an apparent tendency for property developers to incorporate a hotel property in their integrated development projects which also comprise residential, commercial and retail properties. While most property research reports and commentaries prepared by industry professionals generally focused on residential, retail and commercial sectors, very little comments or analysis are made on the hotel sub-sector. Such increased interest in the development of hotel properties especially in the Klang Valley area, coupled with a general lack of research and statistics on the key determinants of hotel, have been the motivating forces that led to the conception of this research to study the key drivers of hotel performance in the Klang Valley, Malaysia.

\section{BACKGROUND OF STUDY}

While property developers are jumping onto the bandwagon to offer a hotel property in their integrated mixed use developments in the Klang Valley, it is unclear what basis, if any, was used by the developers in arriving at the decision to provide a hotel component in their product offerings. Thus, there has been an increased demand for data and statistics to justify the feasibility of a hotel 
property to be incorporated in the integrated property developments. Based on research carried out on hotel investments in Australia, it was found that the main factors influencing hotel investment decision making were financial and location, followed by economic, diversification and relationship factors (Newell \& Seabrook, 2005).

To understand the key determinants that drive hotel performance, empirical research conducted on hotels in Milan found that there were five main determinants, namely number of rooms, number of employees, number of years since the last refurbishment, market orientation, and location that drive hotel performance as measured by Revenue Per Available Room (RevPAR) (Sainaghi, 2010). Limited studies and research were conducted on hotel properties in Malaysia to address the following questions:-

a) What are the key determinant(s) that drive the performance of hotels as measured by RevPAR?

b) Of the key determinants that drive hotel performance, what are the hotel guests' assessments of the importance of each factor in their decision making process?

c) What is the relationship between the key determinants that drive hotel performance and guests' perception of the importance of these determinants?

Therefore, this study aims to achieve two (2) main objectives:-

a) To identify the key determinants of performance for hotels in the Klang Valley.

b) To determine hotel guests' perception of the importance of each of the key determinants identified above.

In order to achieve the above objectives, the mixed method (quantitative and qualitative) is adopted by the way of questionnaire surveys to hotel guests and structured interviews are conducted among hoteliers.

This study analysed the key factors that drive performance of hotels in the Klang Valley with particular focus on upscale hotels located in Kuala Lumpur City Center, where there is the largest concentration of existing hotels as well as numerous new hotels currently under construction or scheduled to be built in the near future. Three (3) key indicators, namely revenue per available room (RevPAR), occupancy rate, and average room rate (ARR), were used to measure the performance of the hotels.

As performance data for hotels are generally regarded as sensitive and confidential information by the hoteliers, coupled with lack of active association for hoteliers in Malaysia, the key determinants were not readily available from any public domain. However, recent key performance data of major hotels in the Klang Valley were compiled by a private company which specialises in hotel consultancy work, MIHR Consulting. Reports of the 2012 performance data of hotels in Kuala Lumpur were purchased from MIHR Consulting, and they are used as the performance yardstick upon which the analysis of this study is based. To ensure the relevance of the subject of this study to encompass both business as well as leisure travellers, this study has focused on hotels in the midscale (i.e. 4 star) and upscale (i.e. 5 star) categories. The selection of hotel operators was based on convenient sampling of ten (10) major hotels located in Kuala Lumpur City Center, KL Sentral, and Sub-urban locations. Hence, economy and budget hotels are not included in the scope of this study as these are typically not the category of hotels occupied by business travellers, and the inclusion of budget and economy classes in the study would have resulted in a skewed analysis as they would preclude participants who travel and stay in hotels for business purposes. 


\section{PERFORMANCE INDICATORS IN HOSPITALITY INDUSTRY}

The indicators that are most widely used and accepted as proxies for performance in the hotel industry are (Damonte et al., 1997):-
(a) Occupancy (\%)
(b) Average Daily Rate (ADR), and
(c) Rooms revenue per available room (RevPAR)

Despite the wide acceptance of the above indicators by hotel practitioners, investment community, independent hotel consultants, analysts, and hotel property owners alike, all the above indicators are susceptible to issues of unreliable measures and flawed interpretations. This section provides a synopsis of the relevant research findings on the inherent limitations of the above performance indicators, with the view that readers are informed of such limitations on the performance indicators that are used.

\section{ROOM OCCUPANCY}

Room occupancy is the measure of room supply efficiency or capacity utilisation. It is calculated by dividing room nights available by room nights sold, and the output is in turn expressed as a percentage. The Uniform System of Accounts for the Lodging Industry defines total occupancy very loosely as rooms in use divided by rooms available (American Hotel \& Motel Association, 1997). According to research conducted by Slattery (2002), differing and flawed treatments and measurements of rooms available and rooms in use could result in a combination of deflated rooms available and inflated rooms in use which in turn boosts room occupancy percentage and provides a false reflection of room supply efficiency.

\section{Average Daily Rate}

Average daily rate is the disaggregated measure of room demand value and it is calculated by dividing rooms turnover by room nights sold for the period under review. If rooms turnover and rooms nights sold are not secure then reported average daily rate cannot be regarded as an accurate reflection of rooms demand value. (Slattery, 2002)

\section{Revenue per available room}

RevPAR is the measure of the balance between hotel room supply and demand and can be calculated in two (2) ways:-

(a) Average daily room rate multiplied by room occupancy percentage, or

(b) Rooms turnover divided by room nights available. Conceptually, it is an effective indicator of hotel room supply and demand performance. However, there are practical limitations and flaws in the measurement of the above indicator, such that hoteliers tend to adopt different interpretations in the compilation of data. For instance, the followings are excluded from hotels total room stocks by some hoteliers:-

- rooms which are under refurbishment,

- rooms used by house employees,

- for seasonal resorts, rooms which are closed during low seasons, 
All of the above treatments tend to have the effect of depressing the total number of room nights available, thus producing an inflated RevPAR. In other instances, complimentary rooms given to high rollers of casino hotels and room nights redeemed by members of hotel loyalty programs tend to inflate the data on room nights sold, thus inflating the RevPAR (Slattery, 2002).

\section{DETERMINANTS OF HOTEL ROOM RATE}

According to research conducted by Zhang et al (2011), the majority of previous studies on the price determinants of hospitality industry have adopted the Hedonic Pricing Models (HPM), which assumes that the price of a product is a linear function of a bundle of items (Kevin-Kam \& King, 2010; Slattery, 2002; Yoo et al., 2010). Essentially, the basic premise of the earlier studies based on HPM was that room price is linked to the presence or absence of various hotel items. (i.e. the existence of a certain item will influence hotel quality, and the quality will influence a consumer's willingness to pay.

Zhang et al. (2011) examined the hotel guests' reviews on online travel advice websites (e.g. tripadvisor.com) on hotels in New York, and concluded that the quality of hotel attributes is evidenced through customer reviews on a travel advice website. The theory of the hierarchy of needs is supported in the hotel industry, namely, the ascending order of accommodation needs are the (1) quality of a room, (2) location, and (3) service. These are the three most important determinants of room price for the hospitality industry. The researchers also distinguished the hotel industry into three segments, namely Luxury Hotels (4-5 star); Midscale Hotels (3-3.5 star); Economy (1-2.5 star) and found that the attributes that can influence hotel room rates vary greatly among the different hotel segments.

In another study conducted by O'Neil and Carlback (2011) on comparing the performance of branded and independent hotels during different economic cycles, the researchers concluded that brand matters, and more so when times are bad. This is because brands may reduce the volatility of the business and present a less risky investment. In addition, the researchers found that brand also matters as a driver of the business value itself, as brand name generate intangible asset value to the hotel.

In summary, the review of relevant literatures on the subject matter - the determinants of hotel room rate - revealed the following key factors which were found to be key drivers of hotel room rate : -
(a) Location
(b) Service
(c) Quality of room (i.e. amenities, size of room etc)
(d) Brand affiliation

\section{CONSUMER BEHAVIOUR AND FACTORS AFFECTING HOTEL PERFORMANCE}

To ascertain whether any of the factors as identified by researchers as key determinants of hotel property value, one needs to consider how these factors are evaluated by the end-users (i.e. hotel guests) in their decision-making process. Bull (1994) noted that "consumer behaviour theory suggests that a decision to choose one product over another may be influenced by perhaps half a dozen determinant attributes of that product". Alpert (1971) concluded that for an attribute to be determinant it must be: 
a) Important to a consumer, as a product benefit (or disadvantage); the relative importance of each attribute to a consumer if it's salience;

b) Differentiable between products.

The hospitality industry in general, and the hotel industry in particular, have witnessed continuous increase in competition for high service quality and customer satisfaction (Quintal \& Polczynski, 2010; Vandell, 2007). Hotel organisations, therefore, need to understand with as much precision as possible, what the guests want from the service experience. Ladhari (2009), seeking to understand the role of customers' emotions during service encounters, concludes that emotional satisfaction is derived from service-quality evaluation, and that hospitality organisations should therefore focus on more than cognitive satisfaction but should also pay attention to the emotional aspect of satisfaction.

Kevin-Kam and King (2010) went a step further to argue that customer satisfaction merely means that customers are at ease but they are not necessarily excited by the firm. Organisations should strive towards delivering services that "delight" the customers. Delighted customers are not only excited but are likely to give positive word of mouth referrals to others, and delight has been linked to other positive outcomes including customer retention, higher profitability and may create a competitive advantage that is difficult to imitate.

With the increasing turbulence in the global environment, the field of hospitality (and its related research) must assess and provide strategic approaches to address challenges and opportunities in the future. While there is increased attention on the relevant research in the areas of valuation, performance, branding, customer loyalty, IT and service delivery systems for hospitality sector, as evidenced from the review of the four (4) top hospitality journals, there remains gaps in research especially with regard to having a holistic view in establishing the key determinants that affect hotel's performance, which are in turn evaluated in relation with the consumers' behaviour to ascertain the relationship (if any) between the two. The outcome of this research would provide added insights to hotel owners and operators in appreciating the hotel guests' assessments of the importance of factors that drive the performance of their hotel properties. Hotel owners and operators could then formulate their business strategies which are cohesive and well aligned among the various stakeholders in the value chain of hospitality sector.

\section{DISCUSSION OF THE RESEARCH FINDINGS}

In this part, the primary data collected from questionnaires were analysed against the performance of major hotels in the Klang Valley.

\section{GUEST AND HOTEL SURVEYS}

Based on the 93 responses obtained for the Guest Questionnaires and ten responses from hoteliers, the data were input into SPSS Statistics for analysis.

\section{SUMMARY OF TOP FIVE FACTORS}

The factors which are shaded in grey in Table 1 are the top five (5) factors which are perceived to be the most important by the surveys when making decision to select a hotel rooms. 
Table 1: SPSS Output for Guest and Hotel Surveys

\begin{tabular}{|ll|c|c|c|c|c|c|}
\hline \multirow{2}{*}{ Determinant } & \multicolumn{3}{|c|}{ Guest Survey } & \multicolumn{3}{c|}{ Hotel Survey } \\
\cline { 3 - 8 } & $\mathbf{N}$ & Mean & $\begin{array}{c}\text { Standard } \\
\text { Deviation }\end{array}$ & $\mathbf{N}$ & Mean & $\begin{array}{c}\text { Standard } \\
\text { Deviation }\end{array}$ \\
\hline$(1)$ & Location & $\mathbf{9 3}$ & $\mathbf{4 . 4 8 3 9}$ & $\mathbf{. 7 1 6 4 7}$ & $\mathbf{1 0}$ & $\mathbf{4 . 6 0 0 0}$ & $\mathbf{. 5 1 6 4 0}$ \\
$(2)$ & Size of Hotel & 93 & 3.3118 & 1.05272 & 10 & 2.8000 & .42164 \\
$(3)$ & Scale & $\mathbf{9 3}$ & $\mathbf{3 . 6 9 8 9}$ & $\mathbf{. 8 1 8 0 7}$ & 10 & 4.2000 & .78881 \\
$(4)$ & Affiliation & 93 & 3.1290 & .82391 & 10 & 4.2000 & 1.03280 \\
$(5)$ & F\&B Outlets & 93 & 3.4516 & 1.03752 & 10 & 3.7000 & .94868 \\
$(6)$ & Room Size & $\mathbf{9 3}$ & $\mathbf{3 . 7 2 0 4}$ & $\mathbf{. 7 8 5 2 7}$ & $\mathbf{1 0}$ & $\mathbf{3 . 3 0 0 0}$ & $\mathbf{. 9 4 8 6 8}$ \\
$(7)$ & Room Rate & $\mathbf{9 3}$ & $\mathbf{4 . 1 2 9 0}$ & $\mathbf{. 8 1 0 6 1}$ & $\mathbf{1 0}$ & $\mathbf{4 . 5 0 0 0}$ & $\mathbf{. 5 2 7 0 5}$ \\
$(8)$ & Service Quality & $\mathbf{9 3}$ & $\mathbf{4 . 4 0 8 6}$ & $\mathbf{. 7 1 0 7 3}$ & $\mathbf{1 0}$ & $\mathbf{4 . 8 0 0 0}$ & $\mathbf{. 4 2 1 6 4}$ \\
$(9)$ & Amenities & 93 & 3.6344 & 1.00850 & 10 & 3.7000 & .94868 \\
$(10)$ & In-house reservation & 93 & 3.5806 & .88861 & 10 & 4.9000 & .31623 \\
$(11)$ & 3rd party reservation & 93 & 3.3226 & .95737 & 10 & 2.8000 & .42164 \\
$(12)$ & Loyalty Program & 93 & 3.2688 & .99061 & $\mathbf{1 0}$ & $\mathbf{4 . 4 0 0 0}$ & $\mathbf{1 . 0 7 4 9 2}$ \\
\hline
\end{tabular}

The outcome of Hotel Questionnaires above are compared against the outcome of the Guest Questionnaires and summary of comparison is shown in Table 2 below:-

Table 2: Comparison of Top 5 Factors (Guest vs. Hotel)

\begin{tabular}{|c|l|l|}
\hline \multirow{2}{*}{ Rank } & \multicolumn{2}{|c|}{ Top Five Factors } \\
\cline { 2 - 3 } & \multicolumn{1}{|c|}{ Guest } & \multicolumn{1}{c|}{ Hotel } \\
\hline 1 & Location & In-house reservation system \\
\hline 2 & Service Quality & Service Quality \\
\hline 3 & Room Rate & Location \\
\hline 4 & Room Size & Room Rate \\
\hline 5 & Scale & Guest Loyalty Program \\
\hline
\end{tabular}

From Tables 1 and 2, it is apparent that both groups of stakeholders (i.e. Guests and Hotel Operators) have somewhat differing perceptions about the top five most important factors. This outcome is not unexpected as both groups of stakeholders have different needs and requirements pertaining to the subject matter. The hotel guests perceived that location, service quality, room rate, room size, and scale of hotel are the five most important factors when they make decision to choose a hotel room versus the other. On the other hand, the hotel operators perceived the in-house reservation system, service quality, location, room rate and guest loyalty program are the five most important factors that affect the performance of their hotel.

\section{CONCLUSION}

This research has provided some findings on the association between key factors perceived as important by hotel guests, and their correlation with the performance of hotels in the Klang Valley. This outcome is valuable in reinforcing the plausibility of using a hotel's performance in the derivation of business value aspect of a hotel valuation. Further research could be conducted to extend the scope to include the association of hotel's performance to the ultimate valuation of the 
hotel property, viewed from the perspective of a hotel property owner. This would complete the entire spectrum in assessing the investment returns potential of a hotel property to the property owner.

It is envisaged that this research has provided useful insights for the relevant stakeholders in a hotel property, namely hotel owners, hotel operators, and hotel guests, to have a better appreciation of the key factors that are important in driving the purchase behaviours of hotel guest, and that such factors have in turn been found to be highly correlated with the performance of hotels. These research findings would be of great interests especially to the hoteliers in devising their marketing and operational strategies such that sufficient focus is given to the key determinants which are of particular importance to hotel guests in driving their decision to select a hotel room.

\section{REFERENCES}

Alpert, M.L. (1971). Identification of determinant attributes: A comparison of methods. Journal of Marketing Research, 8, pp. 184-191.

American Hotel \& Motel Association. (1997). Marketing in the hospitality industry, AHMA-USA.

Bull A.O. (1994). Pricing a motel's location. International Journal of Contemporary Hospitality Management, 6(6), pp.10-15.

Crick A.P. \& Spencer A. (2011), Hospitality quality: New direction and new challenges. International Journal of Contemporary Hospitality Management, 23(4), pp.463-478.

Damonte L.T., Romp P.D., \& Bahl, R.D.J. (1997). Brand affiliation and property size effects on measures of performance in lodging properties. Hospitality Research Journal, 20(3), pp.116

Kevin-Kam F.S. \& King C. (2010). When experience matters: Building and measuring hotel brand equity. International Journal of Contemporary Hospitality Management, 22(4), pp.589-608.

Ladhari,.R. (2009) A review of twenty years of service SERVQUAL research. International Journal of Quality and Service Sciences, 1(2), pp. 172-198.

Newell G. \& Seabrook R., (2005). Factors influencing hotel investment decision making. Journal of Property Investment and Finance, 24(4), pp. 279-294.

Nilsson M., Harris P.J., \& Kett R. (2001). Towards a valuation framework for hotels as business entities. International Journal of Contemporary Hospitality Management, 13(1), pp.6-12.

O’Neill, J.W., \& Carlback, M., (2011), Do brand's matter? A comparison of branded and independent hotel's performance during a full economic cycle. International Journal of Hospitality Management, 30, 515-521.

Quintal V.A. \& Polczynski A. (2010). Factors influencing tourists' revisit intentions. Asia Pacific Journal of Marketing and Logistics, Vol. 22 No.4, 2010, pp. 554-578.

Sainaghi R., (2010). Hotel performance: State of art. International Journal of Contemporary Hospitality Management, 22(7), pp.920-952.

Slattery P. (2002). Reported ReVPAR: Unreliable measure, flaws interpretations and the remedy. International Journal of Contemporary Hospitality Management, 21(4), pp.135-149.

Vandell K.D. (2007). Expanding the academic discipline of real estate valuation - A historical perspective with implications for the future. Journal of Property Investment and Finance, 25(5), pp. 427-443.

Yoo M., Lee S., \& Bai B. (2010). hospitality marketing research from 2000-2009 - topics, methods and trends. International Journal of Contemporary Hospitality Management, 23(4), pp.517532.

Zhang Z., Ye Qi. \& Law R. (2011). Determinants of hotel room price - an exploration of travellers. International Journal of Contemporary Hospitality Management, 23(7), pp. 972-981. 